\title{
THE IDENTIFICATION OF THE FIRST SIXTEEN RELIEFS ON THE SECOND MAIN-WALL OF BARABUDUR.
}

\author{
B Y \\ BAHADUR CHAND SHASTRI M. A., M. O. I.
}

It has already been discovered by Prof. Dr. N. J. Krom that the reliefs on the second main-wall of the Barabudur temple follow the text of Gandavyūha, a Buddhist Sanskrit work wherein the travels of a banker's son named Sudhana in search of Bodhi are narrated. Prof. Krom has also, comparing two summaries ${ }^{\mathbf{1}}$ ) of the text, given a correct identification of many of those reliefs, in his monumental work entitled 'Barabudur' (in two volumes), but it remained a complaint with him that the two summaries at his disposal were neither complete nor reliable enough. Consequently some of the reliefs could not be identified at all, whereas some others had to be only conjecturally identified. A series of the very opening scenes, depicted on the reliefs no's $2-15$, were left almost unidentified, the two summaries being totally reticent over them. The present article is, therefore, intended to set the curiosity about them at rest, and is to be treated as a mere supplement to Prof. Krom's work.

The writer has had an advantage of comparing, not any summary but the text itself which he obtained by the courtesy of Prof. Dr. J. Rahder ${ }^{2}$ ). The whole text covers three volumes or 1488 leaves written on one side only, in Devanāgarī characters, and, though here and there sprinkled over with glaring mistakes, is fairly readable. In details it is simply overwhelming. The sculptor has, no

\footnotetext{
1) One by M. M. Hara Prasāda Sāstrī and the other by Rajendra Iāla Mitra; both quoted in extenso in Prof. Krom's 'Barabudur'.

$\left.{ }^{2}\right)$ I should gratefully record that the present copy of the text - one of the only twenty mimeographs in the world, and the only one out of Japan, the rest all being still there - has been presented to Prof. Rahder by his friend, Yamada Ryūjō Esq., Prof of Sanskrit, Ryūkoku Buddhist College, Kyōto, Japan.
} 
doubt, done full justice in clepicting them on the reliefs as faithfully as his art could permit, still the text sometimes outruns the reliefs by far.

Below I give a summary of the first three chapters of the text, which comprise the descriptions that are represented on the first sixteen reliefs. The present summary has been extracted specially for the purpose of the identification in question, some such details, therefore, had to be included as could easly be dispensed with, in a summary in the true sense of the word. The reference to the pages of the text may be of some avail, I am aware, only to those few for whom the similar text is accessible.

\section{The Summary.}

"It was in the Great Towering Palace (mahāvyūhe kūṭāgāre) in the garden of Anāthapiṇ̣adāsī at Jetavana in Çrāvastī where once the Lord lived, accompanied firstly by five thousand Bodhisattva's with Samantabhadra and Mañjuçrī at their head (p. 4), secondly by five hundred Çrāvaka's and thirdly by Lokendra's (p. 13).

Now it occurred to those Bodhisattva's, Çrāvaka's and Lokendra's that it was impossible for gods and mortals alike to comprehend the powers of the Lord Tathangata without the latter's favour (p. 14). They, therefore, wished in their hearts that the Lord could manifest to them some of his miraculous powers, of his own accord (apyeva nāma Bhagavān asmākan̉..... sanindarçayed) (p. 15).

The Lord, having understood their heart's desire, condescended and adopted a certain posture-of-meditation (samādhi) called Siniha vijrmbhita (pp. 17, 18). And soon after, the interior of the Great Towering Palace became immensely expanded (ananta-madhyavipulah sanisthito' bhüt). The floor was strewn with flowers, gems, jewels and ornaments etc. There shone magnificent pillars, arches, attics, windows and balconies, all made of diverse precious stones (vaiḍuryastambhopaçobhito ..... sarva-ratna-niryūha-toraṇa-harmyagavākșāsarinkhyeya-vedikā-viçuddha-vyūhah etc.) (p. 18). Also there were hoisted umbrellas, standards and flags (samucchrita-cchatra(hvaja-patākāh). On all sides, there were flights of steps, and towers of gems and jewels (samanta-dik-sopāna-mani-ratna-kūṭah) (p. 19).

Similarly the whole of Jetavana was also extended in breadth anil length, and along with that, expanded the fields of Buddha (Buddhakṣetrāṇi) wherein flooded the streams of scented water (gandhodakanadyo etc.) with flowers afloat and gem-trees all around, inter- 
spersed with beautiful buildings with various flags flying on thei: towers (pp. 19, 20).

In the sky there hovered clouds of divine aerial cars (divya. vimāna-megha etc.), fragrant trees (gandha-vṛksa-megha etc.), various musical instruments (vādya-turya-megha etc.), gem-lotuses (ratna-padma-megha etc.), reflectional forms of divine beings (devendra-bimba-saḍ̣çābhimukha-maṇi-vigraha-megha etc.) etc. etc. (p. 21).

All this through the incomprehensible powers of the Lord! (p. 22).'

Hereafter the text repeats in a summarily manner the foregoing description, with some fresh details, e.g. "the clouds of standards and banners borne by the heavenly damsels (dhvaja-patāka-megha divya-kanyā-pāni-gṛhita etc.), and the ornamental representations of lions, necklaces and wreathes carved in precious stones (sarva-ratna bimba-jāla-sinina-pañ jara-nānā-ratna-citra-hāra-mālyālañkārāḥ etc.) (p. 24)."

Soon after the expansion of the Great Towering Palace as well as of Jetavana, and the consequent ornamentation, there followed another great miracle, viz.: "Out of the Buddha-kṣetra's of the ten different Tathāgata's, the occupiers of the ten different quarters ${ }^{1}$ ) - east, south, west, north, north-east, south-east, south-west, northwest, below and above - there issued ten Bodhisattva's ${ }^{2}$ ) one after another, every one of whom, followed by a train of other Bodhisattva's, and showing works of marvel ${ }^{2}$ ) peculiar to himself, came to where the Lord was i.e. Jetavana. There every one of the ten Bodhisattva's, having bowed to the Lord, betook himself to the corner corresponding to the quarter he had issued from, and, having constructed through his marvellous power (abhinirmāya) palaces (kūṭāgārāṇi) and lotus-seats (... padma-garbhāṇi simhāsanāni), sat, crushing down the bed under him (paryankam àbhujya) and supporting the ornamented bodies of the Bodhisattva's that followed him (.... alañkārācchannāni bodhisattva-çarīrāṇy adhiṣthāya) (pp) 24 $-48)$."

"Thus the whole Jetavana was filled by those Bodhisattva's, namely, by the support of Tathāgata's (bodhisattvailı sarvani Jetavanani paripūrṇam abhūc! yaduta tathāgatānām adhiṣthānena) (p. 50).

1) Their proper appellations are suppressed here.

2) Their proper names as. well as the marvels they showed are mentioned while dealing with the identification of the corresponding reliefs, in the following pages. 
All that was seen only by the Bodhisattva's and the Lokendra's; as for the Çrāvaka's-those headed by Çāriputra, Maudgalyāyana, Mahākāçyapa, Raivata, Subhūti, Aniruddha, Nandika, Kapphina. Kātyāyana, Pūrṇa and Maitrāyaṇiputra, as well as those headed by Agrayuga and Bhadrayuga-sitting before, behind and on either side of the Lord as they were, they saw neither the Lord in his Simhavijrmbhita Samaidhi nor the miracles he harl shown (bhagavatal! purato vāma-dakṣiṇa-prọthato bhagavato 'bhimukhani saniniṣaṇnā na ca tâni jetavane buddhavikurvitāny adrākṣuḷ etc. (p. 55), viz. the expansion of the Great Towering Palace and Jetavana, the decorations and the gathering of the great multitude of Bodhisattva's under the ten chief ones who themselves, in their turn, showed various marvels; because the Çrãvaka's were not merited enough for such a vision (pp. 50-67).

Then those ten Bodhisattva's, one after another, chanted the praise of the Lord (pp. 67-88)." Here ends the first chapter.

"After that. Samantahhadra Bodhisattva first expounded (sainprakāçayati sma) to all the Bodhisattva's present there the same Sinihavijrmbhita Samādhi of the Lord, and then chanted his praise (pp. 89-94).

Next, the Lord, with a view to instruct the Bodhisattva's in the self same Simhavij̣̣mbhita Samãdhi (atraiva simhavij̣̣mbhite samādhau samniyojanārthan p. 94), emitted forth from between his eyebrows (bhrūvivirāntarād ūrṇākoçāt etc. p. 94) a certain beaming ray which illumined all the ten quarters, and by the light of which all the Bodhisattva's assembled in Jetavana visualized the Lord under the Bodhimanḍavara on a Bodhisattva-simināsana, worshipped by all the Lokendra's, and preaching in the homes of Nàga's Yakșa's, Gandharva's, Asura's, Garuḍa's etc. etc. (pp. 94-96).

Then, from the bodies of the Bodhisattva's, who were sitting on the lotus-seats (.... padnuagarbhasininhāsana-niṣaṇnānāin p. 106) and who were illumined by the ray of the Lord (tathăgata-raçmyavabhāsitānanin p. 112), there issued forth various clouds which showed diverse things e.g. jewel-bells (mani-ghaṇțā-meghāh etc.) musical instruments (vādyamegháh etc.) forms of Nāga's, Gandharva's, Rși's etc. pp. 96-114).

At this occasion, Mañjuçrī Bodhisattva chanted the praise both of the Lord and his sons (sugatātmajāh) i.e. Bodhisattva's who surrounded him p. 115-117).

Again from the bodies of those Bodhisattva's, there darted forth 
many rays and clouds showing Bodhisattva's scattered everywhere preaching in different guises - some as Çramana's, others as Brāhmaṇa's, Vaidya's, Vaṇik's, Çrutājīva's, Nartaka's, Devalaka's etc. etc. pp. 117-122)." Here ends the second chapter.

"Now Mañjuçrī Kumārabhūta Bodhisattva took leave of the Lord and set out on his journey to Dakṣināpatha, followed by a great number of Bodhisattva's, different deities and gods. Seeing this, Çāriputra also followed him, accompanied by sixty Bhikṣu's. On his way, Mañjuçrī preached to those Bhikșu's and continued his journey. His first halt was in a Caitya called Vicitrasāladhvaja vyūha which was situated near to the east of the city of Dhanyākara. As soon as the citizens heard the news of Mañjuçrī's arrival, they hegan to pour in in great numbers and thronged the Caitya-hall. Among the visitors, there was also a group of bankers and that was headed by one named Sudhana. Sudhana was so called because his birth brought his parents an immense wealth - as soon as he was born, there emerged seven sprouts of gems, digging which the father discovered seven treasures. Mañjuçrī preached to the audience, and recognised in Sudhana a person fit to receive the Sublimest Knowledge (anuttarā samyak-saninbodhi).

Mañjuçri then left that place and resumed his journey. Sudhana went after him, praised him and besought him for the Sublimest Knowledge. Mañjuçrī approved of Sudhana's earnest desire and advised him to approach a Bhikṣu named Meghaçrī on the Mount Sugrīva in the province of Rāmāvarānta or Rāmāvartta in the same Dakṣināpatha pp. 123-156)." Here ends the third chapter.

After reading this story, one may find it easy to identify the corresponding reliefs. But before proceeding to that, I may call attention to the following two points. First: according to the textual order, the scene, wherein the Çrãvaka's deprived of the sight of the Lord and his miracles are depicted, ought to have succeeded the ten scenes of the ten Bodhisattva's on the reliefs, but on the contrary, there it preceds them. Second: we miss the description correspon-ding to the relief No. 11.

I venture to give my own explanation of this.

Regarding the first point, the first possibility is that the sculptor might have followed a text different from the one we have. The second possibility is that the sculptor might have wilfully depicted 
the scene of the Çrāvaka's immediately after that of the Lord, thinking that, if depicted after ten scenes, it would lose its importance. It was the Lord whose sight the Çrāvaka's were deprived of ; and that they could not see his miracles was only a consequence. So this importance certainly would have been obscured, if the scene of the Çrāvaka's were depicted after the interval of ten or eleven reliefs.

As regards the second point, my three perusals of the first 156 pages of the text have yielded me no details corresponding to the relief No. 11. It is curious enough that this relief differs widely from its neighbouring ones. No incense-burner, no Bodhisattva's with their characteristic head-dresses, the small pavilion with two figures in it beside the main pavilion, and behind it some human figures with hair and moustaches, are some of the peculiarities of this relief. Here also it seems probable that the sculptor might have had a different text. I am, however, hopeful to come across the theme of this relief somewhere in the text yet unread. A similar discrepancy came to my notice, while I was glancing further through the text, comparing at the same time the corresponding reliefs, but it was instantly removed when I turned some few hundred pages more. Thus such inconsistencies may be better discussed when we shall have a summary of the whole text at our disposal. I am attempting at such a one, and may be able to bring it out before long, in instalments, if not all at once.

Now we proceed with the identification.

1. Buddha, Bodhisattva's, Çrāvaka's and Lokendra's.

The Lord is seaterl in his Simhavij̣̣mbhita Samādhi, surrounded by Bodhisattva's, Çrāvaka's and Lokendra's.

The text describes Boddhisattva's and Lokendra's as 'saparivārāh' and not so Çrāvaka's. If we admit that the word 'parivāra' does not here mean only 'retinue' but also 'family', then it may account for the female figures on the relief.

The other details of the relief, as for instance: the arch, the umbrella or the cushion-like thing on the top of it, the pillars, the musical instruments, the ornamental figures of lions etc., are all in agreement with the text.

The figures of lions may also have a reference to the Lord's Sinihavị̣rmbhita Samādhi. 


\section{2. Çrāvaka's.}

This relief represents the two groups of the Çrāvaka's mentioned above. The Lord and his miraculous works were invisible to them. The building is less decorated here, because the decoration was one of the Lord's miracles to see which the Çrāvaka's had no right, otherwise they are in the same kūtāgāra.

3. A Bodhisattva, occupying the eastern corner.

Vairocana-pranidhānābhiraçmiprabha is his name, and he is described to have showered clouds of heavenly flowers, garlands, ornaments, clothes, gems, jewels etc. which are recognizable on the relief. The figures around the central one represent the Bodhisattva's that follewed their chief.

4. A Bodhisattva, occupying the southern corner.

Duryodhanaviraya-vega-rāja is his name, and he came supporting multitudes of Buddha-kșetra's decorated with diverse necklaces, flowergarlands, ornaments, clothes etc. (sarva-ratna-hāradāma-jālāvanaddhān sarva-buddlha-kṣetra-prasarān adhitișțan) (p. 27).

5. A Bodhisattva, occupying the western corner.

Samanta-çrī-samudgata-tejo-rāja is his name, and he came embellishing the whole region of Dharma with clouds of different flowers. flags, incense-smoke, and mounts of gems and jewels etc. (vividhagandha-kusuma-meghail ..... gandha dhūpa-meghaih..... jyotir-dhwaja-mani-ratna-sumeru-meghaih etc. sarva dharm dhātuin spharan pp. $28-29)$.

6. A Bodhisattva, occupying the northern corner.

Asanga-Çrī-garbha-rāja is his name, and he came supporting the firmament adorned with clouds of gems and clothes of various hues (kanaka-çrī-jvalana-maṇiratna-vastra-meghālañkāragaganatalam adlhitișthan etc. pp. 32-33).

7. A Bodhisattva, occupying the north-east corner.

Dharma-dhātu-sunirmita-praṇidhi-candra is his name ,and he came supporting all the quarters covered with clouds of kūtāgāra's full of diverse precious stones and fragrant incense-articles (ratnakūṭāgāra-megha-saninchannān sarva-loka-chātuprasarān adhitișthan, 
gandha-kuṭā... dhūpakuṭ̄à ... candanakīṭā ... maṇi-kūṭā... etc. pp. $34-35$ ).

8. A Bodhisattva, occupying the south-east corner.

Dharmārcissamtejas is his name, and he came covering the sky with clouds of variegated rays reflecting gem-trees and branches, lotus-flowers etc. (ratna-druma-çākhā-maṇụala-maṇi-rāja-varṇa-prabhā-maṇ̣lala-meghaị̣ sarvanin gagana-talani saninchādayan etc. pp. $36-37)$.

9. A Bodhisattva, occupying the south-west corner.

Sarva-māra-maṇḍala-vikiraṇa-jñāna-dhwaja is his name, and he came showering clouds of rays reflecting flower, musical instruments, gems and jewels, incense, clothes etc. (.... kusumārci-meghān pramuñcan, .... vādyārci ...., maṇi-ratnārci .... gandha-dhūpa .... etc. etc. pp. 38,39$)$.

10. A Bodhisattva, occupying the north-west corner.

Vairocana-praṇidhi-jñana-ketu is his name, and he came emitting forth clouds of the reflections of the bodies of Tathāgata's, Bodhisattva's, Parṣat maṇ̣ala, Buddha-nirmāṇacakra, Çrāvaka’s, etc. etc. (.... tathāgata-kāỵa-pratibimba-meghān niçcāraỵan etc. pp. 40-42).

11. An unidentified relief.

12. A Bodhisattva, occupying the space below.

Sarvāvaraṇa-vikiraṇa-jñāna-vikrāmin is his name, and he came, blowing forth from the pores of his body different kinds of uproarious proclamations (sarva-roma-vivirebhyal .... sarva-jaganmantrasvara-nirukti-nirhāra-nirghoṣān niçcārayan, .... bodhisattva-prasūtinaya-sāgara-megha-nirghoṣān nigarjan etc. pp. 43, 44).

\section{A Bodhisattva, occupying the space above.}

Dharma-dhātu-praṇidhi-tala-nirbheda is his name, and he came manifesting in bright hues multifarious forms of the previous Buddha's (sarva-bodhisattva-parivārasyātmano bhaga-vataçca vairocanasya p)ūrvānta-koṭigatānāin . . . daçasu dikṣu pūrvayoga-samudrān pratibhāsa prāptān sanilarçayan etc. pp. 45-47).

With regard to the identification of the foregoing ten reliefs, 
I have withheld much of the textual monotony, and have avoided unnecessarily vexing the reader by pointing out the details of the reliefs, corresponding to the text. I may, however, add that whereever the sculptor seems to have taken liberty in depicting such details as do not accord with the text, it is partly to break the dullness and partly because he had sometimes to depict abstract ideas as nirghoșān etc. A certain uniformity is, however, kept up in these ten reliefs, and that was desirable.

\section{Samantabhadra.}

In the pavilion is seated Samantabhadra, explaining the significance of the Simhavijrmbhita Samādhi of the Lord to the crowd of the Bodhisattva's assembled in Jetavana; and on the relief (they are) depicted in the three rows, all attentive to Samantabhadra.

\section{Lord Buddha and Bodhisattva's.}

Quite corresponding to the text, Buddha is depicted here as seated under the Bodhi-tree, surrounded by the Bodhisattva's resting on the lotus-seats, with heavenly attendants in the sky.

16. Mañjuçrī and Sudhana.

This relief has already been identified with perfect certainty by Prof. Krom. It represents the conversation between Mañjuçrī and Sudhana.

For further details, the reader is requested to consult Prof. Krom's 'Barabudur'. 
